\title{
DEM ASSESSMENT DERIVED FROM CLOSE RANGE PHOTOGRAMMETRY: A CASE STUDY FROM KADAVUR AREA, KARUR DISTRICT, TAMIL NADU, INDIA
}

\author{
S. Anbarasan ${ }^{\mathrm{a}, *}$, R.Sakthivel ${ }^{\mathrm{b}}$ \\ ${ }^{a}$ Reserach Scholar, Centre for Remote Sensing, Bharathidasan University, Tiruchirappalli, Tamil Nadu, India - \\ sjanbarasan@gmail.com \\ ${ }^{\mathrm{b}}$ Assistant Professor, Centre for Remote Sensing, University, Tiruchirappalli, Tamil Nadu, India - \\ drsvel@gmail.com
}

Commission V, WG V/6

KEY WORDS: Digital Close Range Photogrammetry (DCRP), DEM Assessment, Commercial Digital camera.

\begin{abstract}
:
Close-Range Photogrammetry is an accurate, cost effective technique of collecting measurements of real world objects and conditions, directly from photographs. Photogrammetry utilizes digital images to obtain accurate measurements and geometric data of the object or area of interest, in order to provide spatial information for Engineering design, spatial surveys or 3D modeling. The benefits of close-range Photogrammetry over other field procedures are purported to be: Increased accuracy; complete as-built information; reduced costs; reduced on-site time; and effective for small and large projects. The same basic principle of traditional Aerial Photogrammetry can be applied to stereoscopic pictures taken from lower altitudes or from the ground. Terrestrial, ground-based, and close-range are all descriptive terms that refer to photos taken with an object-to-camera distance less than $300 \mathrm{~m}$ (1000 feet). (Matthews, N.A, 2008). Close range Photogrammetry is a technique for obtaining the geometric information (e.g. position, distance, size and shape) of any object in 3D space that was imaged on the two dimensional (2D) photos, (Wolf, P.R, et.al, 2000) DEM Generation requires many processing and computation, such as camera calibration, stereo matching, editing, and interpolation. All the mentioned steps contribute to the quality of DEM. Image on close range Photogrammetry can be captured using three kind of camera: metric camera, semi-metric camera, and non-metric camera (Hanke, K., et.al, 2002). In this paper DEM quality assessed at Kadavur area, Karur district, Tamil Naudu, India using Close Range Photogrammetry technique, Commercial Digital Camera and Leica Photogrammetry Suite.
\end{abstract}




\section{INTRODUCTION}

\subsection{Digital Elevation Model}

Digital Elevation Model (DEM) is a digital data represented an easting northing and height of object position, in which it can be derived from many data sources and techniques. One such method is a close-range Photogrammetry. It is a technique for obtaining three dimensional (3D) geometric information of any object that was imaged on two dimensional (2D) photographs by an analytical stereo model. Analytical stereo model involves three main steps; interior, relative, and absolute orientations. It requires Ground Control Points (GCP) to determine positions and orientation of the camera and also parameters of coordinate transformations. By these orientations coordinates all features on overlapping area can be transformed into ground coordinate system.

\subsection{DCRP Technique}

Digital Close Range Photogrammetric digital methods have been successfully applied to many applications such as archaeology, architecture, automotive and aerospace engineering, accident reconstruction and etc (Carbonell, 1989; Atkinson, 1996). With the rapid development in technology, improvement of hardware and software products have affected development in digital close range Photogrammetry. Some studies can be made more economically, more accurately and faster using the recent digital close range Photogrammetry technology or technique. A major advantage with photogrammetric methods is the positive relationship between photo scale and precision. Typically high precision is required for studies involving small areas (i.e large scale photography) and a lower precision is acceptable for larger areas (i.e smaller scale imagery is most efficient) (Chandler et al., 2001).

\subsection{The concepts of precision, accuracy and reliability in relation to DEM Quality Assessment}

The overall "quality" of the elevation data produced using stereomatching algorithms is of fundamental importance in this research, because this will directly affect any roughness statistics calculated from the DEMs. The quality of a DEM is a function of the accuracy, reliability and precision of the survey/photogrammetric measurements and the block bundle adjustment itself. In order to construct a thorough, systematic data quality assessment procedure, it is necessary to identify the different types of potential errors and their sources (Table 1) and to quantify the probability of there being errors of a specified size and type. Blunders or mistakes which occur during survey measurement, photogrammetric measurement or stereomatching may be referred to as gross errors; these can be considered to determine the reliability of the DEM (Table I). Cooper and Cross (1988) define reliability as "a measure of the ease with which outliers may be detected". In their assessment of the quality of survey data sets, Cooper and Cross (1988) also make the distinction between internal reliability and external reliability. Internal reliability is seen as the size of the marginally detectable gross error in a measurement whereas external reliability is a measure of the effect of this error on the parameters (for example, co-ordinates) or on data computed from them. The tau factor ( $\mathrm{t} i$ ) can be used to quantify the internal reliability of a particular survey measurement and this is simply the ratio of the standard error of a measurement to that of the corresponding correction (Cooper and Cross, 1988).

\begin{tabular}{|c|c|c|}
\hline Sources/causes of error & Methods of assessment & Methods of correction \\
\hline \multicolumn{3}{|l|}{$\begin{array}{l}\text { RANIDOM ERROR (PRECISION) } \\
\text { (1) W.r.t. survey measurements }\end{array}$} \\
\hline $\begin{array}{l}\text { Varlation in the measurement } \\
\text { process. }\end{array}$ & $\begin{array}{l}\text { Repeat measurements of the same } \\
\text { element. Covariance matrix used } \\
\text { to compute local and global } \\
\text { measures of preclision. }\end{array}$ & Cannot be removed. \\
\hline \multicolumn{3}{|l|}{ (ii) W.r.t. digital photogrammetry } \\
\hline Low SNR. & $\begin{array}{l}\text { Precision estimate calculated during } \\
\text { stereomatchling from the SNR and } \\
\text { the negatlve curvature of the } \\
\text { correlation curve. }\end{array}$ & $\begin{array}{l}\text { Improve image } \\
\text { quality. }\end{array}$ \\
\hline \multicolumn{3}{|l|}{ 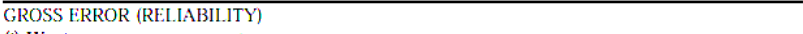 } \\
\hline $\begin{array}{l}\text { (1) W.r.t. survey measurements } \\
\text { Incorrect measuring/recording } \\
\text { procedures. }\end{array}$ & $\begin{array}{l}\text { Assessment of individual } \\
\text { measurement residuals obtained } \\
\text { from least squares estlnation. }\end{array}$ & $\begin{array}{l}\text { Selective removal of } \\
\text { gross errors. }\end{array}$ \\
\hline $\begin{array}{l}\text { Internal rellability is the marginally } \\
\text { detectable gross error. External } \\
\text { rellabillty is the effect of undetected } \\
\text { error on derived co-ordinates. }\end{array}$ & $\begin{array}{l}\text { Calculation of the tau factor }\left(\tau_{i}\right) \\
\text { and computatlon of the upper } \\
\text { bound on the gross error that can } \\
\text { be detected in the fh measurement } \\
\text { with a given probabilitity. }\end{array}$ & \\
\hline \multicolumn{3}{|l|}{ (ii) W.r.t. digital photogrammetry } \\
\hline $\begin{array}{l}\text { Internal rellability. Incorrect fixes } \\
\text { durlng stereomatching due to: } \\
\text { poor image contrastiquality: } \\
\text { poor trlangulation: } \\
\text { non-optimal DEM collection } \\
\text { paraneters: errors in ground point } \\
\text { measurenent and identification: } \\
\text { effects of vlewing geometry. }\end{array}$ & $\begin{array}{l}\text { Analysis of DEM collection results } \\
\text { and comparison of DEM points with } \\
\text { independent elevatlon data to identify } \\
\text { individual blunders. Overlapping } \\
\text { DEMs (redundant data) can also be } \\
\text { used to provlde (semt-) independent } \\
\text { estimates of surface elevation. }\end{array}$ & $\begin{array}{l}\text { Blunder editing. Improve } \\
\text { image contrast and } \\
\text { qualitity improve } \\
\text { triangulation by } \\
\text { reviewing functional } \\
\text { modelss. optimize IIEM } \\
\text { collection parameter set } \\
\text { for specific applications: } \\
\text { re-measure GCP's. }\end{array}$ \\
\hline $\begin{array}{l}\text { External reliabillty. Effect of false } \\
\text { fixes on DEM derived data (for } \\
\text { example, roughness parameters). }\end{array}$ & $\begin{array}{l}\text { Analysis of the effect that a } \\
\text { marginally detectable error in the } \\
\text { hh measurement has on a } \\
\text { particular parameter. }\end{array}$ & \\
\hline \multicolumn{3}{|l|}{$\begin{array}{l}\text { SYSTEMATIC ERROR (ACCURACY) } \\
\text { (i) W.r.t. survey measurements }\end{array}$} \\
\hline $\begin{array}{l}\text { Atmospheric and other physical } \\
\text { effects. Instrument errors and } \\
\text { incorrect pointing. }\end{array}$ & $\begin{array}{l}\text { Extension of functional models to } \\
\text { include systematic errors. Systematic } \\
\text { errors which can be successfully } \\
\text { estimated from the survey } \\
\text { measurements can then be modelled. }\end{array}$ & $\begin{array}{l}\text { Cannot be fully } \\
\text { eliminated but review of } \\
\text { functional models where } \\
\text { necessary can be used to } \\
\text { mitigate against their } \\
\text { effects. }\end{array}$ \\
\hline $\begin{array}{l}\text { (ii) W.r.t. digital photogrammetry } \\
\text { Insufficiently convergent imagery. }\end{array}$ & $\begin{array}{l}\text { Ensure convergence angle of } 20^{\circ} \text { to } \\
40^{\circ} \text { when vaquiring imagery. }\end{array}$ & \\
\hline $\begin{array}{l}\text { Over-simplification of the } \\
\text { measurement process (for example. } \\
\text { ignoring the effects of lens distortion } \\
\text { when these should be considered). } \\
\text { Physical effects include camera lens } \\
\text { distortions. atmospheric refraction. } \\
\text { film unflatness. }\end{array}$ & $\begin{array}{l}\text { Independent accuracy assessment and } \\
\text { assessment of the significance of } \\
\text { additional (for example. interior } \\
\text { orientation) parameters within the } \\
\text { functional models. }\end{array}$ & \\
\hline
\end{tabular}

Table 1. Types and sources of error in conventional survey and close range digital photogrammetry.

Local measures of precision require the variance of individual parameters to be computed from the covariance matrix of the parameter. Global measures of precision, such as the a posteriori variance of unit weight (the variance factor), can be used to quantify the effects of random errors in a complete set of co-ordinates or other derived quantities. The precision of automated image measurement and stereomatching is positively related to (i) the number of pixels that are associated with a target (Chandler and Padfield, 1996); and (ii) the signal-to-noise ratio (SNR) of the imagery (Vision International, 1995). Higher image SNRs also lead to fewer gross errors (false fixes) in the stereomatched DEMs

In this paper a method for to trace the $\mathrm{mm}$ size structures and minerals by increasing the point density in Aero Triangulation process.

\subsection{Instrumentation}

Since the aim of this research is to assess the DEM derived from Digital Close Range Photogrammetry. The equipment and software used were easy to get and its availability.

i) Sony Digital Camera: 10.2 Mega Pixels

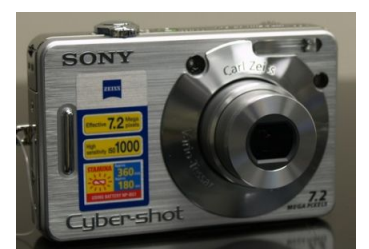

Figure: 1 Sony Digital Camera 


\begin{tabular}{|c|c|}
\hline Megapixel & $7.2 \mathrm{MP}$ \\
\hline Imaging Device & $1 / 2.5^{\prime}$ Super HAD ${ }^{\mathrm{TM}}$ CCD \\
\hline Recording Media & 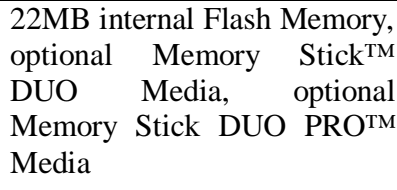 \\
\hline LCD & $\begin{array}{l}\text { 2.4" (112K Pixels TFT LCD } \\
\text { Screen) }\end{array}$ \\
\hline Lens Construction & $\begin{array}{lccr}6 \text { Elements } & \text { in } & 5 & \text { Groups } \\
\text { (including } & 3 & & \text { aspheric } \\
\text { elements) } & & & \\
\end{array}$ \\
\hline Lens Type & Sony \\
\hline Still Image Mode(s) & JPEG: Normal, Burst \\
\hline Focal Length & 5.8 to $17.4 \mathrm{~mm}$ \\
\hline $35 \mathrm{~mm}$ Equivalent & $35-105 \mathrm{~mm}$ \\
\hline Focus & $\begin{array}{ll}\text { 5-Area Multi-Point AF, } \\
\text { Center AF }\end{array}$ \\
\hline Focal Distance & $\begin{array}{l}\begin{array}{l}\text { Normal Minimum: } 19 \\
(50 \mathrm{~cm})\end{array} \\
\end{array}$ \\
\hline Aperture & $\begin{array}{l}\text { Auto and Program Auto: } \\
\text { f2.8(W) - f9.7(T) }\end{array}$ \\
\hline Optical Zoom & $3 X$ \\
\hline Digital Zoom & 0-2.0X (Precision) \\
\hline Minimum Focus Distance & $\begin{array}{l}\text { W: Approx. } 19 \text { 11/16(50cm) - } \\
\text { Infinity / T: Approx. } 19 \\
\text { 11/16(50cm) - Infinity }\end{array}$ \\
\hline Dimensions (Approx.) & $\begin{array}{l}3-5 / 8 " \text { × } 2-3 / 8 " \text { × } 11 / 8 "(91.4 \\
\text { x } 61 \text { × } 29.1 \mathrm{~mm})\end{array}$ \\
\hline Weight (Approx.) & $\begin{array}{l}4.9 \mathrm{oz}(140 \mathrm{~g}) \text { Body; } 6.7 \mathrm{oz} . \\
(189 \mathrm{~g}) \text { including Battery and } \\
\text { optional Memory Stick }{ }^{\circledR} \\
\text { DUO Media }\end{array}$ \\
\hline $\begin{array}{l}\text { Operating } \\
\text { Compatibility }\end{array}$ & $\begin{array}{l}\text { Microsoft® } 2000 \text { Professiona, } \\
\text { XP Home and Professional, } \\
\text { Macintosh® OS 9.1/9.2, OS X } \\
(10.0-10.4)\end{array}$ \\
\hline
\end{tabular}

\section{Table 2: Technical Specifications of SONY DSC S730}
ii) Leica Photogrammetry Software.
iii) Global Mapper.
iv) Garmin GPS

\section{STUDY AREA}

\subsection{Study Area}

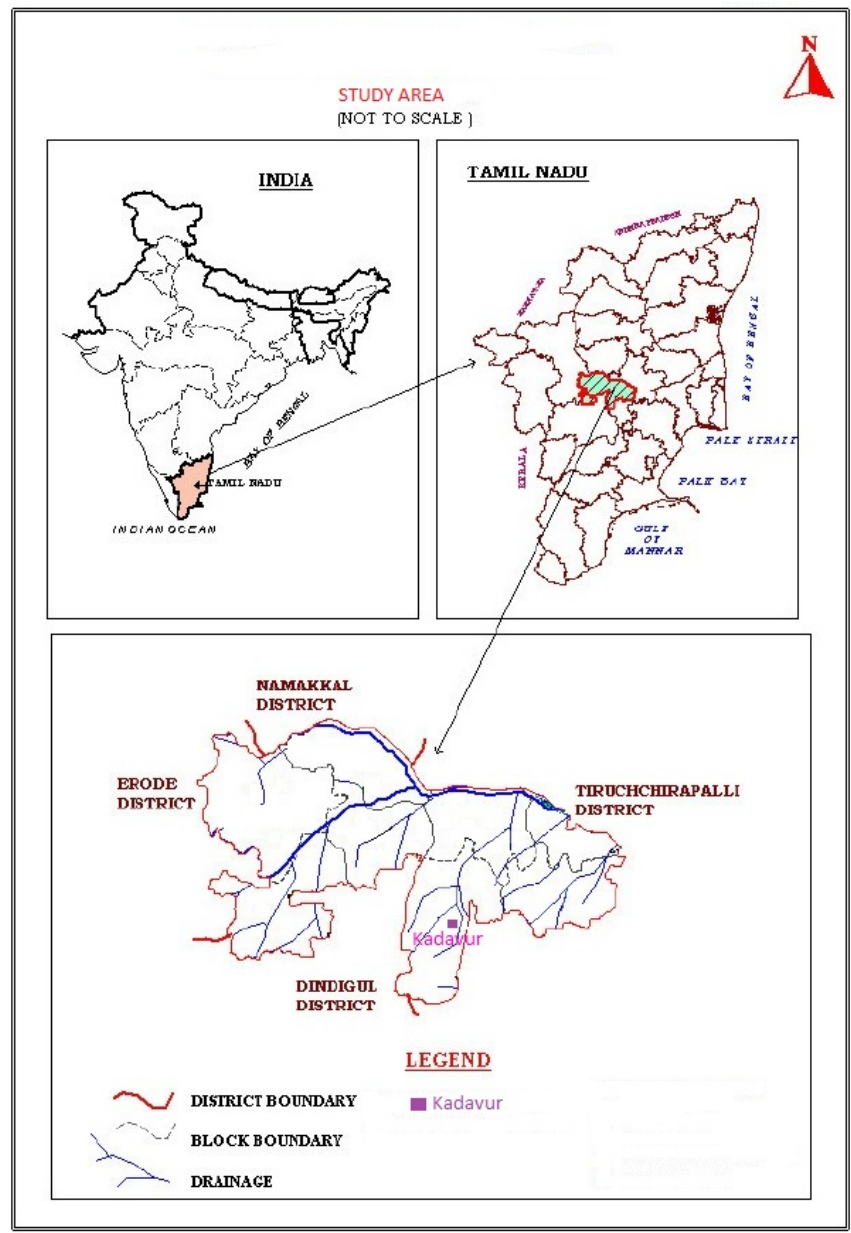

Figure 2: Location map

Karur district is divided into 4 taluks. The taluks are further divided into 8 blocks, which further divided into 203 villages.

\begin{tabular}{|c|c|c|c|c|c|c|}
\hline S.No & Name of taluk & Area in ha. & $\begin{array}{l}\text { No. of } \\
\text { villages }\end{array}$ & Name of blocks & $\begin{array}{l}\text { Area in } \\
\text { ha. }\end{array}$ & $\begin{array}{l}\text { No. of } \\
\text { villages }\end{array}$ \\
\hline \multirow[t]{2}{*}{ I } & \multirow[t]{2}{*}{ Karur } & \multirow[t]{2}{*}{60643} & \multirow[t]{2}{*}{52} & 1. Karur & 24335 & 26 \\
\hline & & & & 2. Thanthoni & 36308 & 26 \\
\hline \multirow[t]{2}{*}{2} & \multirow[t]{2}{*}{ Aravakurichi } & \multirow[t]{2}{*}{97616} & \multirow[t]{2}{*}{58} & 1. Aravakurichi & 43689 & 22 \\
\hline & & & & 2. K.Paramathi & 53927 & 36 \\
\hline \multirow[t]{2}{*}{3} & \multirow[t]{2}{*}{ Kulithalai } & \multirow[t]{2}{*}{49081} & \multirow[t]{2}{*}{45} & 1.Kulithalai & 18903 & 24 \\
\hline & & & & 2. Thogamalai & 30178 & 21 \\
\hline \multirow[t]{3}{*}{4} & \multirow[t]{2}{*}{$\begin{array}{l}\text { Krishnarayapur } \\
\text { am }\end{array}$} & \multirow[t]{2}{*}{82217} & \multirow[t]{2}{*}{48} & \begin{tabular}{|l|} 
I. \\
Krishnarayapur \\
am
\end{tabular} & 39503 & 28 \\
\hline & & & & 2. Kadavur & 42714 & 20 \\
\hline & Total & 289557 & 203 & & 289557 & 203 \\
\hline
\end{tabular}

Table 3: Karur Taluk and Block details

\subsection{Geology of Tamil Nadu and Kadavur}

Crystalline rocks of Archaean to late Proterozoic age occupy over $80 \%$ of the area of Tamil Nadu, while the rest is covered by Phanerozoic sedimentary rocks 
mainly along the coastal belt and in a few inland River valleys. The hard rock terrain comprises Charnockite and Khondalite groups and their migmatitic derivatives, supracrustal sequences of Sathyamangalam and Kolar groups and Peninsular Gneissic Complex (Bhavani Group), intruded by ultramafic-mafic complexes, basic dykes, granites and syenites. The sedimentary rocks of the coastal belt include fluviatile, fluvio-marine and marine sequences, such as Gondwana Supergroup (Carboniferous to Permian and Upper Jurassic to Lower Cretaceous), marine sediments of Cauvery basin (Lower Cretaceous to Paleogene), Cuddalore Formation (Mio-Pliocene) and sediments of Quaternary and Recent age. The crystalline rocks of the state are derived through a complex evolutionary history during Archaean and Proterozoic times with multiple deformations, anatexis, intrusions and polyphase metamorphic events, (GSI, 2010-11).

\subsection{Geomorphology of Karur}

The entire area of the district is a pediplain. The Rangamalai hills and Kadavur hills occurring in the southern side of the district constitutes the remnants of the much denuded Eastern Ghats and rise to heights of over $1031 \mathrm{~m}$ above mean sea level. From these hills the district slopes gently towards north east and forms a vast stretch of plain country till the eastern boarder of the district. There are numerous small residual hills represented by Ayyarmalai, Thanthonimalai and Velayuthampalayam hills. The general elevation of the area is ranging between $100 \mathrm{~m}$ and $200 \mathrm{~m}$ above mean sea level The prominent geomorphic units identified in the district through interpretation of Satellite imagery are 1) Structural hill, 2) Pediments, 3) Shallow Pediments, 4) Buried Pediments and 5) Alluvial plain.

\subsection{Soils of Karur}

The soils of Karur district can be broadly classified into 4 major soils types viz., Red Soil, Thin Red Soil, Red Loam and River Alluvium Soil. Red soil is the predominant one covering major part of the district followed by Thin Red soil and Red loam. The red soils are predominantly seen in Kadavur, Kulithalai, Krishnarayapuram, Thanthoni and Thogamalai blocks. The thin red soils are seen in Aravakurichi and K.Paramathiy blocks. Major portion of the Karur block is covered by red loam.

\section{METHODOLOGY}

\subsection{METHODLOGY}

Image management follows the standard approach in LPS_PM (Leica Photogrammetry Suite Photogrammetry Management) software as follows

\begin{tabular}{|c|c|}
\hline Steps & Process Flow \\
\hline 1 & Image Acquisition \\
\hline 2 & Create New project \\
\hline 3 & Add imagery to the block file \\
\hline 4 & Define the Camera Model \\
\hline 5 & $\begin{array}{c}\text { Perform automatic tie point } \\
\text { collection }\end{array}$ \\
\hline 6 & Perform Aerial Triangulation \\
\hline 7 & DEM Generation \\
\hline 8 & DEM Assessment \\
\hline
\end{tabular}

Taple 4. Process Flow

\subsubsection{Image Acquisition}

The Photogrammetric accuracy is dependent on image scale so 3D Modeling of Quarry must be taken by overlapping digital images acquired with Non-Metric camera Sony Alpha DSLR-A230 and focal length vary from $18 \mathrm{~mm}$ to $55 \mathrm{~mm}$ lens. Special care was undertaken so as the horizontal image angles be of small values. This is a fundamental restriction imposed by the structure of the Digital Photogrammetric Stations which are used for Photogrammetric mapping. Wide angles between stereo-pairs do not permit stereoscopic view and as a consequence calculations and three dimensional restitution. The overlapping images has been taken with $20^{\circ}$ to $45^{\circ}$ angle in Kadavur Quarry

\subsubsection{Create New Project}

A new project using Sony digital camera images (7.2 mega pixels) of Kadavur Quarry, Tiruchirappalli, India. The images are in the format of .jpg format. Here transformed Cartesian Co-ordinate system is used as mentioned

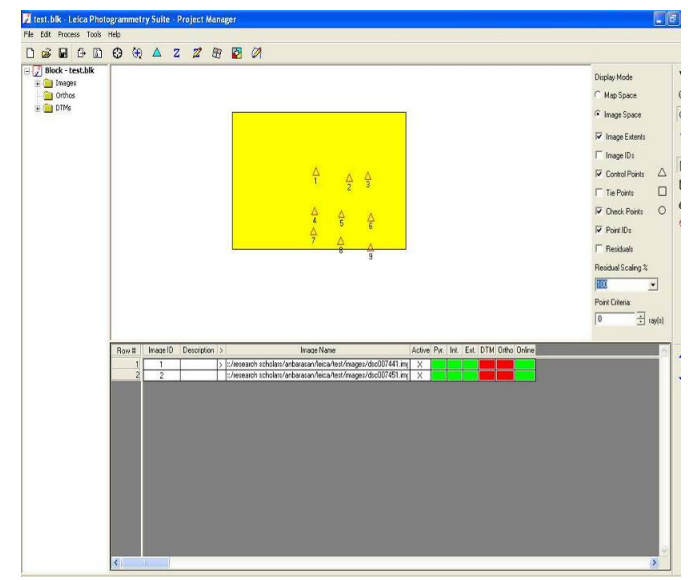

Figure 3: Project Manager in LPS - GCP Points

Decimal numbering of all sections is recommended. If bold printing is not available to you, use underlining, instead, but only for subheadings and subsubheadings, not for Major Headings.

\subsubsection{Add imagery to the block file}

in the LPS project Manager.

Using Add frame tools all the images are added

\subsubsection{Define the Camera Model}

According to this paper, the Sony Digital camera- Cybershot has been used which is entered in the Digital Camera Frame Editor dialog box. And other parameter such as Focal Length, Interior Orientation (pixel size of X0, Y0) and Exterior Orientation.

\subsubsection{Perform automatic tie point collection}

At this point in the process the control points (Fig.4) are collected in overlapping areas of images in the block file that determine the approximate exterior orientation parameters. Using point Measurement tool the Automatic tie point extraction have been carried out. 


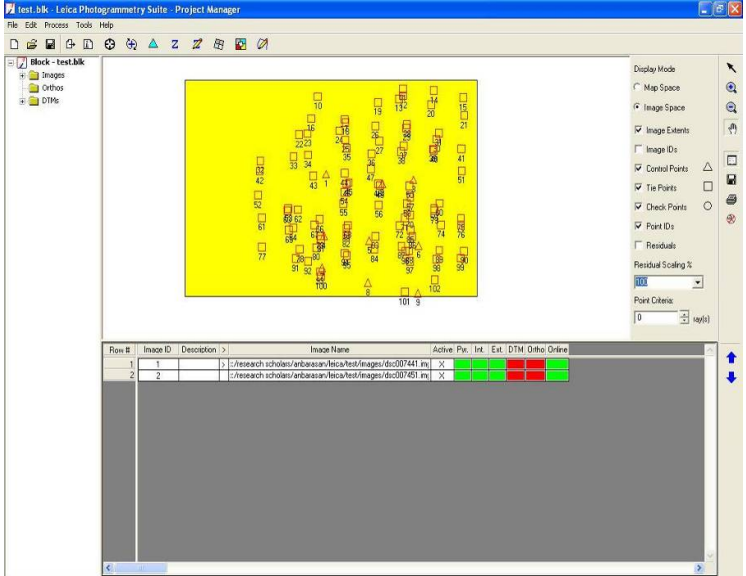

Figure 4: Automatic Tie Points

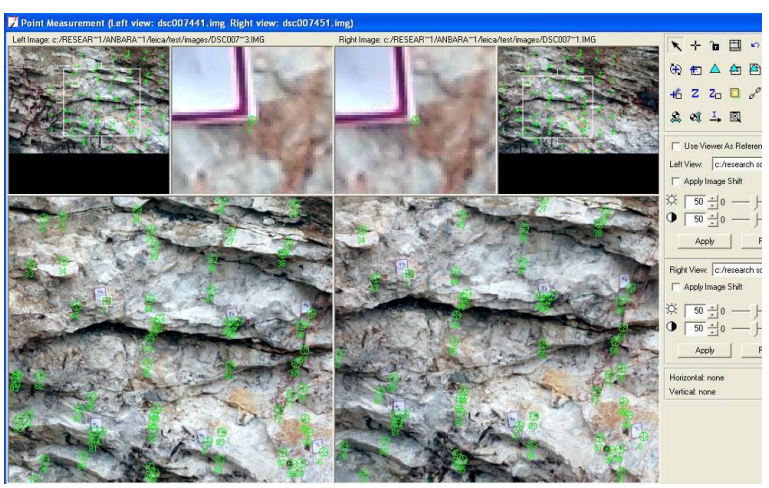

Figure 5: Point Measurement (GCP, Tie points, Check points residual checking)

3.1.6 Perform Aerial Triangulation: Now the control points are added using control point sketch. Then Aerial Triangulation property was setup and the run the AT process. Based on the GCP points and Image points residual error (Fig.7) the adjustment was repeated until the residual error within tolerance.

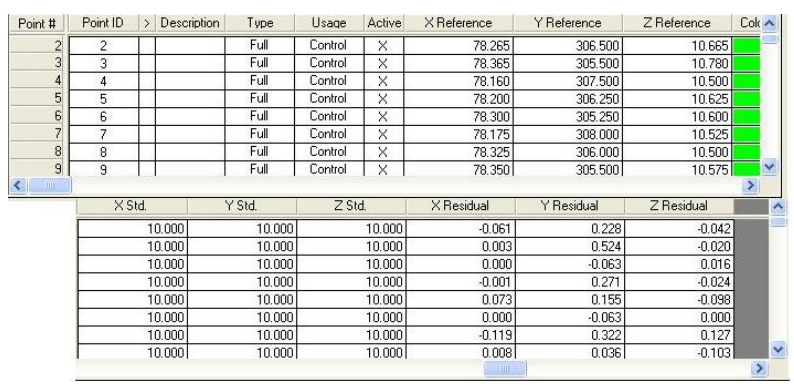

GCP points residual

\subsubsection{DEM Generation}

DEM was generated from all coordinate points resulted from previous stage and then interpolated by Triangular Irregular Network (TIN) method. The TIN method was selected because of the simplicity and it's characteristic to maintain the position of known points.

\subsection{DEM Assessment}

The DEM was generated by adding $10 \%$ of measured points to the particular surface, which the points were well distributed on the surface. The same process was repeated adding each time an additional $10 \%$ of the measured points, until the last DEM was created with $100 \%$ of the points. The point density ranging from $10 \%$ to $100 \%$ given. Each model was then compared to the reference DEM. Each model was then compared to the reference DEM so the morphological of the rock surface were viewed and determined.

\section{RELATIONSHIP BETWEEN RMS ERROR AND POINT DENSITY}

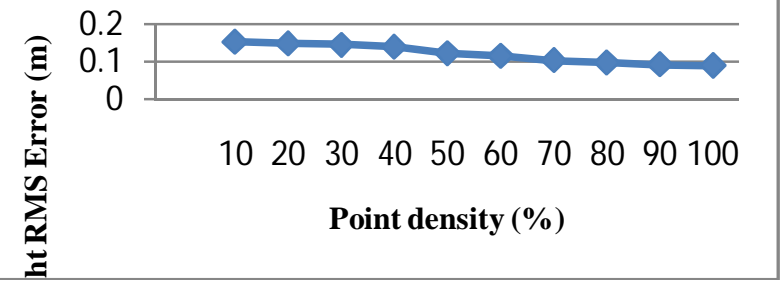

Figure 6: Relationship between RMS Error and Point

\subsection{Field Photos:} Density

The following photos are Field survey photo at Kadavur area.
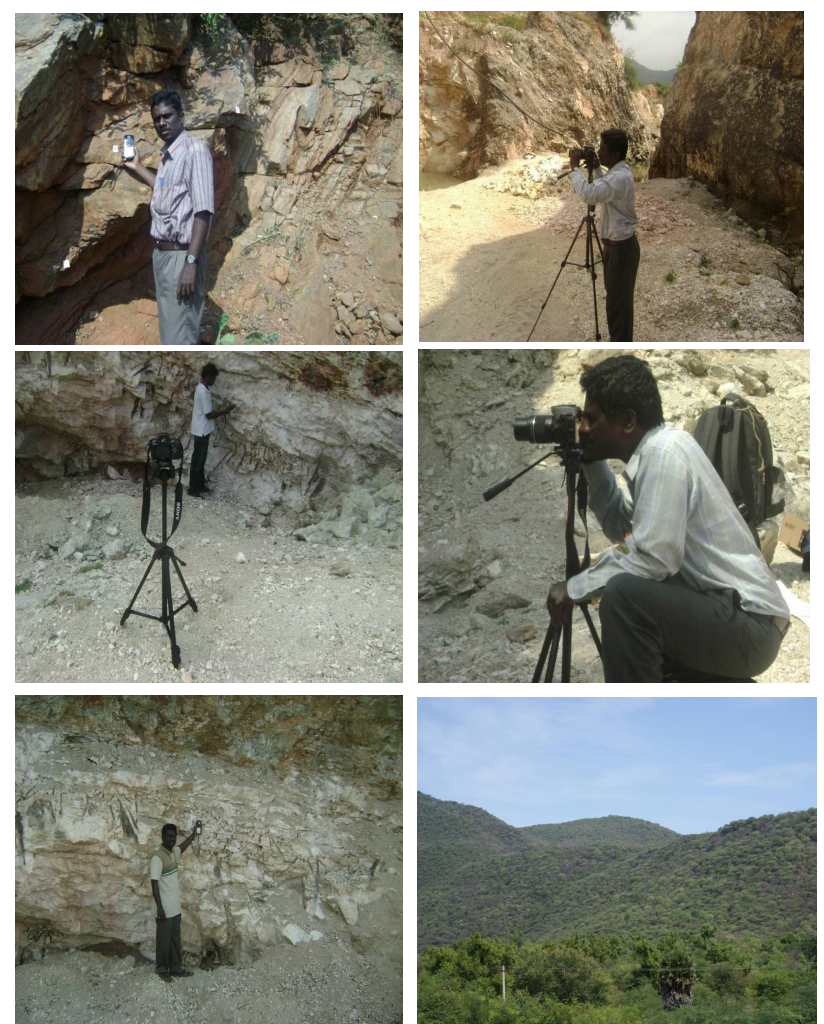

Figure 7: Field Photos 


\subsection{References and/or Selected Bibliography}

\section{References from Journals:}

Atkinson, K.B., 1996. Close Range Photogrammetry and Machine Vision, Whittles Publishing, Scotland.

Carbonell M., 1989. “Arquitectural photogrammetry". In: Karara HM, editor, Non-Topographic Photogrammetry. Falls Church, Virginia: ASPRS

Cooper, M. A. R. and Cross, P.A., 1988. Statistical concepts and their application in photogrammetry and surveying. Photogrammetric Record, 12(71): 637-663.

\section{References from Other Literature:}

Matthews, N.A., 2008. Aerial and Close-Range Photogrammetric Technology: Providing Resource Documentation, Interpretation, and Preservation. Technical Note 428. U.S. Department of the Interior, Bureau of Land Management, National Operations Center, Denver, Colorado. $42 \mathrm{pp}$.

\section{CONCLUSION}

\subsection{Conclusion}

DEM can be derived by using point-based matching from stereo photographs by Digital Stereo Model for Kadavur area. Significant improvement on the DEM quality was achieved by adding point density up to $60 \%$. Increasing point density above $60 \%$ shows minimal variation on the error in elevation interpolation. Digital Close Range Photogrammetry (DCRP) can be applied due to reliability, accuracy, safety and cost advantages over conventional measurement techniques. In addition to these advantages, the 3D models which are obtained can be used for to measure the finite particles of rock surface and it's orientation of structural weakness such as small fracture , small cracks and cleavage. The geological structures are identified such as cleavage, minor cracks and minor fractures and mica assemblages. And any irrespective of the field to gather more finite detail information using DCRP technique. 